\title{
Reducing Cerebral Microvascular Amyloid- $\beta$ Protein Deposition Diminishes Regional Neuroinflammation in Vasculotropic Mutant Amyloid Precursor Protein Transgenic Mice
}

\author{
Jianting Miao, ${ }^{1}$ Michael P. Vitek, ${ }^{2}$ Feng Xu, ${ }^{1}$ Mary Lou Previti, ${ }^{1}$ Judianne Davis, ${ }^{1}$ and William E. Van Nostrand ${ }^{1}$ \\ ${ }^{1}$ Department of Medicine, Stony Brook University, Stony Brook, New York 11794-8153, and ${ }^{2}$ Department of Neurology, Duke University Medical Center, \\ Durham, North Carolina 27710
}

Cerebral microvascular amyloid- $\beta(\mathrm{A} \beta)$ protein deposition is emerging as an important contributory factor to neuroinflammation and dementia in Alzheimer's disease and related familial cerebral amyloid angiopathy disorders. In particular, cerebral microvascular amyloid deposition, but not parenchymal amyloid, is more often correlated with dementia. Recently, we generated transgenic mice (Tg-SwDI) expressing the vasculotropic Dutch (E693Q)/Iowa (D694N) mutant human A $\beta$ precursor protein in brain that accumulate abundant cerebral microvascular fibrillar amyloid deposits. In the present study, our aim was to assess how the presence or absence of fibrillar $\mathrm{A} \beta$ deposition in the cerebral microvasculature affects neuroinflammation in $\mathrm{Tg}$-SwDI mice. Using Tg-SwDI mice bred onto an apolipoprotein E gene knock-out background, we found a strong reduction of fibrillar cerebral microvascular $\mathrm{A} \beta$ deposition, which was accompanied by a sharp decrease in microvascular-associated neuroinflammatory cells and interleukin- $1 \beta$ levels. Quantitative immunochemical measurements showed that this reduction of the neuroinflammation occurred in the absence of lowering the levels of total $\mathrm{A} \beta 40 / \mathrm{A} \beta 42$ or soluble $\mathrm{A} \beta$ oligomers in brain. These findings suggest that specifically reducing cerebral microvascular fibrillar $\mathrm{A} \beta$ deposition, in the absence of lowering either the total amount of $\mathrm{A} \beta$ or soluble $\mathrm{A} \beta$ oligomers in brain, may be sufficient to ameliorate microvascular amyloid-associated neuroinflammation.

Key words: amyloid- $\beta$ protein; transgenic mice; cerebral microvasculature; neuroinflammation; Alzheimer's disease; vasculotropic mutant

\section{Introduction}

Extracellular deposition of the amyloid- $\beta(\mathrm{A} \beta)$ protein in brain is a prominent pathological feature of Alzheimer's disease (AD) and related disorders (Selkoe, 2001). A $\beta$ peptides are derived through sequential proteolytic processing of the $\mathrm{A} \beta$ precursor protein $(\mathrm{A} \beta \mathrm{PP})$ by $\beta$ - and $\gamma$-secretase activities. Cerebral parenchymal $\mathrm{A} \beta$ deposition can occur as diffuse plaques, with little surrounding pathology, or as fibrillar plaques associated with dystrophic neurons and inflammation (Selkoe, 2001). Fibrillar $\mathrm{A} \beta$ deposition in the cerebral vasculature, a condition known as cerebral amyloid angiopathy (CAA), is also commonly found in Alzheimer's disease (Vinters, 1987; Jellinger, 2002; Rensink et al., 2003). Additionally, several familial forms of CAA exist that result from mutations that reside within the $\mathrm{A} \beta$ peptide sequence of

Received Jan. 11, 2005; revised May 24, 2005; accepted May 24, 2005.

This work was supported in part by National Institute of Neurological Disorders and Stroke Grant R01-NS36645, Alzheimer's Association Grant IIRG-02-3995 (W.E.V.N.), and National Institute on Aging Grant R01-AG19780 (M.P.V.). Antibody reagents for the $A \beta E$ ELISAs and the soluble $A \beta$ oligomer-specific rabbit polyclonal antibody were generously provided by Lilly Research Laboratories (Indianapolis, IN) and Dr. W. Klein (Northwestern University, Evanston, IL), respectively.

Correspondence should be addressed to Dr. William E. Van Nostrand, Department of Medicine, Health Science Center T-15/083, Stony Brook University, Stony Brook, NY 11794-8153. E-mail: William.VanNostrand@stonybrook.edu. DOI:10.1523/JNEUROSCI.1306-05.2005

Copyright $\odot 2005$ Society for Neuroscience $\quad 0270-6474 / 05 / 256271-07 \$ 15.00 / 0$
$\mathrm{A} \beta \mathrm{PP}$ gene including the Dutch-type (E22Q) and Iowa-type (D23N), which cause early and severe cerebral vascular amyloid deposition (Levy et al., 1990; Van Broeckhoven et al., 1990; Grabowski et al., 2001). Recent studies have implicated cerebral microvascular $A \beta$ deposition in promoting neuroinflammation and dementia in $\mathrm{AD}$ and related familial CAA disorders (Vinters, 2001; Atterns and Jellinger, 2004; Bailey et al., 2004; Greenberg et al., 2004). In particular, cerebral microvascular, but not parenchymal, amyloid deposition is more often correlated with dementia in individuals afflicted with Alzheimer's disease and CAA disorders (Neuropathology Group of the Medical Research Council Cognitive Function and Ageing Study, 2001; Thal et al., 2003; Atterns and Jellinger, 2004).

Recently, we generated transgenic mice that express human vasculotropic mutant human $\mathrm{A} \beta \mathrm{PP}$ in brain $(\mathrm{Tg}-\mathrm{S} w \mathrm{DI})$ and develop early-onset and robust cerebral deposition of $\mathrm{A} \beta$, particularly in the cerebral microvasculature (Davis et al., 2004). The finding that $T g$ SwDI mice accumulate extensive cerebral microvascular $\mathrm{A} \beta$, despite low levels of transgene human $\mathrm{A} \beta \mathrm{PP}$ expression and human $\mathrm{A} \beta$ production, appears to result from the ineffective clearance of the Dutch/Iowa mutant from brain across the capillary blood-brain barrier into the circulation (Davis et al., 2004; Deane et al., 2004).

In the present study, our aim was to assess how the presence or absence of fibrillar $\mathrm{A} \beta$ deposition in the cerebral microvasculature 
affects neuroinflammation in $\mathrm{Tg}-\mathrm{SwDI}$ mice. Here, we show that reducing fibrillar cerebral microvascular $\mathrm{A} \beta$ deposition in $\mathrm{Tg}$ SwDI mice, through breeding onto an apolipoprotein E (apoE) knock-out background, significantly reduces the number of neuroinflammatory reactive astrocytes, activated microglia, and cerebral interleukin-1 $\beta$ (IL$1 \beta$ ) levels. Notably, these beneficial outcomes were achieved without lowering either the total amount of $A \beta$ peptides in brain or the putatively pathogenic soluble $\mathrm{A} \beta$ oligomers, indicating that the neuroinflammation in the $T g-S w D I$ mice resulted from fibrillar microvascular $\mathrm{A} \beta$ deposition.

\section{Materials and Methods}

Transgenic mice. All work with animals followed National Institutes of Health guidelines and was approved by the Stony Brook University Institutional Animal Care and Use Committee (IACUC) or by the Duke University IACUC. $T g$-SwDI mice were described recently (Davis et al., 2004), and $a p o E^{-/-}$mice were obtained from The Jackson Laboratory (Bar Harbor, ME). All mice were on a pure C57BL/6 background. Tg-SwDI/apoE ${ }^{-/-}$mice were generated by successive breedings of heterozygous $T g$-SwDI mice with the $a p o E^{-1-}$ mice to yield mice that were $\mathrm{Tg}-\mathrm{S} w D I / a p o E^{-/-}$. Eleven $\mathrm{Tg}$-SwDI/apoE ${ }^{+/+}$and $10 \mathrm{Tg}-\mathrm{SwDI} / \mathrm{apoE} \mathrm{E}^{-/-}$ were examined at 12 months of age for the pathological studies.

Tissue preparation. Mice were killed with an overdose of $2.5 \%$ avertin, and the brains were immediately removed and bisected in the midsagittal plane. One hemisphere was snap-frozen and used for the protein analyses. The other hemisphere was placed in $70 \%$ ethanol, followed by xylene treatment and embedding in paraffin for immunohistochemical and histological analyses.

Quantitative immunoblot analysis for cerebral human $A \beta P P$. The levels of human A $\beta P P$ in $T g-S w D I / a p o E^{+/+}$and $T g-S w D I / a p o E^{-1-}$ mouse forebrain was determined by quantitative immunoblotting using the human A $\beta$ PP-specific monoclonal antibody $\mathrm{P} 2-1$ as described previously (Davis et al., 2004).

Immunochemical analysis of cerebral $A \beta$ peptides. Soluble pools of $\mathrm{A} \beta 40$ and $\mathrm{A} \beta 42$ were determined by using a specific ELISA of carbonateextracted mouse forebrain tissue, and, subsequently, the insoluble $A \beta 40$ and $A \beta 42$ levels were determined by ELISA of guanidine lysates of the insoluble pellets resulting from the carbonate-extracted brain tissue (Johnson-Wood et al., 1997; DeMattos et al., 2002). Total A $\beta 40$ and $\mathrm{A} \beta 42$ levels were determined by combining the soluble and insoluble levels of each form. Affinity-purified rabbit polyclonal antibody highly selective for soluble $A \beta$ oligomers was prepared following protocols as described previously (Lambert et al., 2001). Soluble A $\beta$ oligomers were analyzed in TBS-soluble forebrain fractions using dot-blot analysis following previously described protocols (Chang et al., 2003) and quantitated using Bio-Rad (Hercules, CA) VersaDoc system and the Quantity One software.

Immunohistochemical analysis. Immunohistochemistry and histology were performed as reported previously (Davis et al., 2004). Briefly, sections were cut in the sagittal plane at $10 \mu \mathrm{m}$ thickness using a microtome, deparaffinated, and rehydrated. Antigen retrieval was performed by treatment with proteinase $\mathrm{K}(0.2 \mathrm{mg} / \mathrm{ml})$ for $10 \mathrm{~min}$ at $22^{\circ} \mathrm{C}$ for $\mathrm{A} \beta$ and collagen staining and by $10 \mathrm{~mm}$ sodium citrate solution, $\mathrm{pH}$ 9.0, for 30 min at $90^{\circ} \mathrm{C}$ in a water bath for activated microglia staining. Primary antibodies were detected with horseradish peroxidase-conjugated or alkaline phosphatase-conjugated secondary antibodies and visualized either with a stable diaminobenzidine solution (Invitrogen, Carlsbad, CA) or with the fast red substrate system (Spring Bioscience, Fremont, CA), respectively, as substrate. Sections were counterstained with hematoxylin. Thioflavin-S staining for fibrillar amyloid was performed as described previously (Dickson et al., 1990). The following antibodies were used for immunohistochemical analysis: mouse monoclonal antibody 66.1 , which recognizes residues $1-5$ of human $\mathrm{A} \beta$ (1:200) (Deane et al., 2003), rabbit polyclonal antibody to collagen type IV (1:100; Research Diagnostics, Flanders, NJ), mouse monoclonal antibody to glial fibrillary acidic protein (GFAP) for the detection of astrocytes (1:300; Chemicon, Temecula, CA), mouse monoclonal anti-keratan sulfate antibody for the detection of activated microglia (clone, 5D4; 1:200; Seikagaku Corporation, Tokyo, Japan).

Quantitative analysis of regional $A \beta$ deposition and microvascular $C A A$. Total amyloid burden in the regions of the subiculum, dentate gyrus, thalamus, and frontotemporal cortex was respectively quantified on the same set of systematically sampled $A \beta$-immunostained sections using $\mathrm{NIH}$ ImageJ 1.32 software. The percentage of $A \beta$-associated blood vessels in the same fields as above was determined using stereological principles, as described previously (Long et al., 1998).

Quantitative analysis of reactive astrocyte and activated microglia cell densities. Total numbers of astrocytes and activated microglia in the subiculum, dentate gyrus, thalamus, and frontotemporal cortex regions were estimated using a computerized stereology system (Stereologer; Systems Planning and Analysis, Alexandria, VA). Every 10th section was selected and generated $10-15$ sections per reference space in a systematic-random manner. Immunopositive cells were counted using the optical-fractionator method with the dissector principle and unbiased counting rules (Long et al., 1998).

Measurement of cerebral IL-1 $\beta$ levels. Hemibrains isolated from 12month-old $\mathrm{Tg}$-SwDI/apoE $\mathrm{F}^{+/+}$and Tg-SwDI/apoE ${ }^{-1-}$ mice were homogenized in 10 vol of $50 \mathrm{~mm}$ Tris- $\mathrm{HCl}$ and $150 \mathrm{~mm} \mathrm{NaCl}, \mathrm{pH} 7.5$, containing protease inhibitor cocktail (SM Biotech, Huntington Station, $\mathrm{NY})$ at $4^{\circ} \mathrm{C}$. The samples were centrifuged at $14,000 \times g$ for $50 \mathrm{~min}$ at $4^{\circ} \mathrm{C}$. The supernatants were collected, and the protein concentrations were determined using the BCA kit (Pierce, Rockford, IL). The levels of IL- $1 \beta$ in the samples were determined using a mouse IL- $1 \beta$ immunoassay kit (Biosource International, Camarillo, CA).

Statistical analysis. Data were analyzed using Student's $t$ test at a significance level $p=0.05$. 


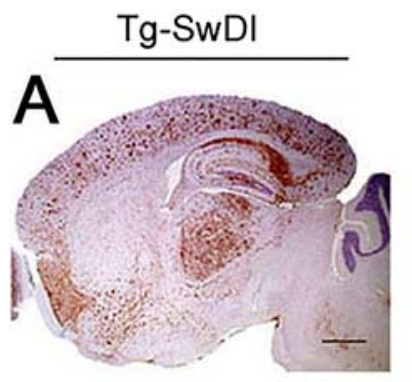

Tg-SwDI x ApoE KO
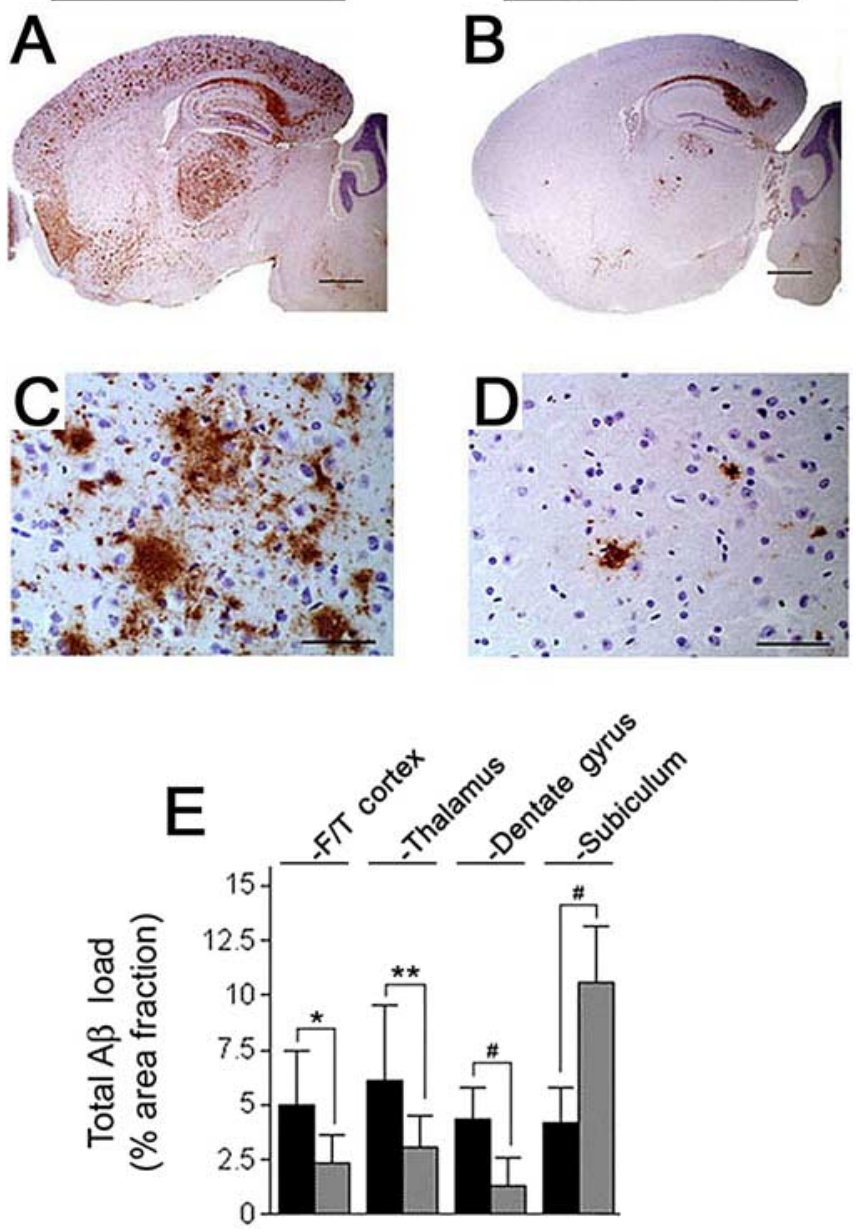

Figure 2. Lack of endogenous mouse apoE lowers cerebral $A \beta$ deposition in $T g-S w D /$ mice. $A-D$, Deposition of $A \beta$ in forebrain $(\boldsymbol{A}, \boldsymbol{B})$ and frontotemporal cortex $(\boldsymbol{C}, \boldsymbol{D})$ in $T g$-SwDl in the absence or presence, respectively, of endogenous mouse apoE. Scale bars: $A, B, 1 \mathrm{~mm} ; C, D, 50 \mu \mathrm{m}$, respectively. $E$, Quantitative image analysis of regional $A \beta$ deposition in $T g$-SwDI mice in the presence (black bars) or absence (gray bars) of endogenous mouse apoE. Data shown are mean $\pm S D(n=10) .{ }^{*} p<0.01$; ${ }^{* *} p<0.02 ; \# p 0.001$. F/T, Frontotemporal; K0, knock-out.

\section{Results}

Accumulation of fibrillar $\mathrm{A} \boldsymbol{\beta}$ exclusively in the cerebral microvasculature of $\mathbf{T g}-\mathrm{S} w \mathrm{DI}$ mice

We reported recently that $T g-S w D I$ mice develop early-onset and robust accumulation of cerebral $\mathrm{A} \beta$ deposits, particularly on the cerebral microvasculature (Davis et al., 2004). Tg-SwDI mice exhibit an age-dependent increase in cerebral microvascular $\mathrm{A} \beta$ accumulation starting at several months of age that becomes very extensive, affecting $\approx 50 \%$ of microvessels in certain regions by 12 months (Davis et al., 2004). To characterize the nature of the cerebral parenchymal and microvascular $A \beta$ deposits in brain sections from 12-month-old $\mathrm{Tg}$-SwDI mice, we performed double labeling and confocal microscopy for $\mathrm{A} \beta$ by immunolabeling and for fibrillar amyloid by thioflavin-S staining. Abundant diffuse $A \beta$ deposits were observed in the cortex that did not stain with thioflavin-S (Fig. $1 A$ ). In contrast, in the thalamic region, for example, numerous microvascular $\mathrm{A} \beta$ deposits were seen that strongly stained with thioflavin- $S$, indicating their fibrillar nature (Fig. $1 B$ ). To confirm that the fibrillar $A \beta$ was localized to the cerebral microvasculature, we performed double labeling and confocal microscopy for microvessels by immunolabeling for
Tg-SwDI
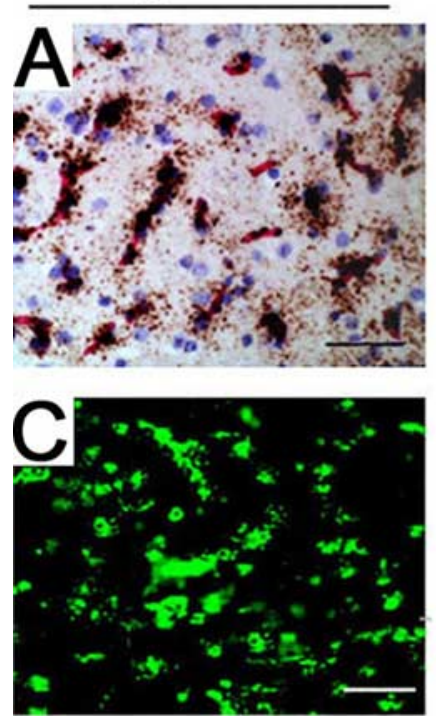
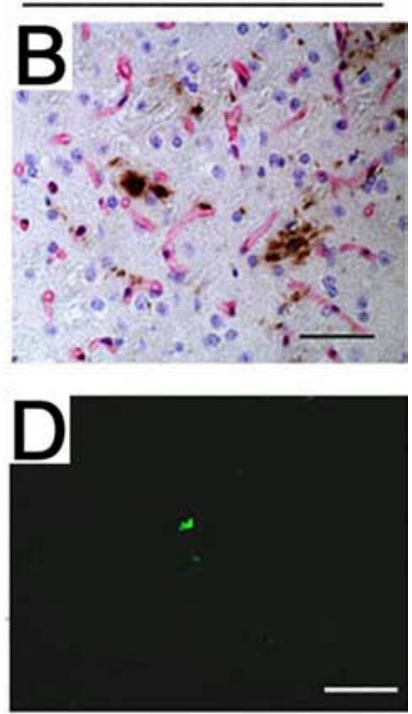

Tg-SwDI x ApoE KO

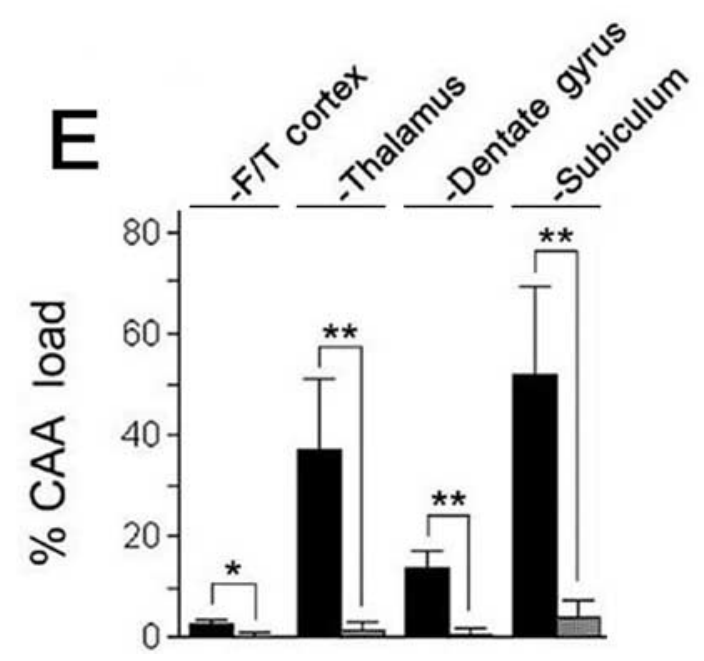

Figure 3. Lack of endogenous mouse apoE eliminates cerebral microvascular $A \beta$ deposition in $T g$-SWDI mice. $\boldsymbol{A}-\boldsymbol{D}$, Fibrillar microvascular amyloid deposition in $T g-S w D /$ mouse thalamus revealed by immunostaining for $A \beta$ (brown) and collagen type IV (red; $A, B$ ) and thioflavin-S fluorescence staining $(\boldsymbol{C}, \boldsymbol{D})$ in the presence $(\boldsymbol{A}, \boldsymbol{C})$ or absence $(\boldsymbol{B}, \boldsymbol{D})$ of endogenous mouse apoE. Scale bars, $50 \mu \mathrm{m}$. $E$, Quantitative stereological estimation of microvascular amyloid deposition in the presence (black bars) or absence (gray bars) of endogenous apoE. Data shown are mean \pm SD $(n=10) .{ }^{*} p<0.01 ;{ }^{* *} p<0.0001$. F/T, Frontotemporal; K0, knock-out.

collagen type IV in conjunction with thioflavin-S staining (Fig. 1C). These results indicate that, in $T g-S w D I$ mice, fibrillar $\mathrm{A} \beta$ accumulation is restricted to the cerebral microvasculature in contrast to the diffuse parenchymal deposits.

\section{Lack of apoE strongly reduces cerebral microvascular $\mathrm{A} \beta$ deposition in $\mathrm{Tg}-\mathrm{SwDI}$ mice}

The major goal of the present study was to assess how the presence or absence of fibrillar $\mathrm{A} \beta$ deposition in the cerebral microvasculature affects neuroinflammation in $T g-S w D I$ mice. The lipid transport protein apoE has been shown to facilitate $\mathrm{A} \beta$ deposition in brain parenchyma and cerebral vessels in humans as well as in human $\mathrm{A} \beta \mathrm{PP}$ transgenic mouse models of $\mathrm{A} \beta$ deposition (Schmechel et al., 1993; Bales et al., 1999; Holtzman, 2001; Chalmers et al., 2003; Fryer et al., 2003; Holtzman, 2004). There- 
fore, to modify $\mathrm{A} \beta$ levels, heterozygous $T g$-SwDI mice were bred onto an apoE knock-out background, and the resulting $\mathrm{Tg}$-SwDI/apoE $\mathrm{E}^{-1-}$ mice were compared with $T g$-SwDI/apoE $E^{+/+}$mice littermates at 12 months of age. There was a significant decrease $(p<0.01)$ in the extent of total $\mathrm{A} \beta$ deposition by $\approx 50 \%$ in the regions of the hippocampus, thalamus, and neocortex in $T g-S w D I / a p o E^{-1-}$ mice compared with $\mathrm{Tg}$-SwDI/apoE $\mathrm{E}^{+/+}$mice (Fig. $2 A, B$ ). The one regional exception was the subiculum, which presented a surprising, more than twofold increase in parenchymal $A \beta$ deposition (Fig. 2B). These results are consistent with findings that endogenous mouse apoE facilitates cerebral A $\beta$ deposition in human $\mathrm{A} \beta \mathrm{PP}$ transgenic mice (Bales et al., 1999; Holtzman, 2001; Fryer et al., 2003; Holtzman, 2004). However, the lack of apoE only reduced, but did not prevent, diffuse parenchymal $\mathrm{A} \beta$ deposition in $\mathrm{Tg}-\mathrm{S} w \mathrm{DI}$ mice.

In contrast to the parenchyma, a more striking decrease in the amount of cerebral microvascular $\mathrm{A} \beta$ was observed with a nearly complete loss of cerebral microvascular amyloid deposits in the Tg-SwDI/apoE ${ }^{-/-}$mice (Fig. 3). Quantitative stereological measurements confirmed the virtually complete elimination of cerebral microvascular $\mathrm{A} \beta$ load in animals lacking apoE compared with those expressing apoE (Fig. $3 A, B$ ). Even within the subiculum, in which there was a pronounced increase in parenchymal $\mathrm{A} \beta$ deposition $(p<0.001)$ (Fig. $2 B$ ), there was also a highly significant abolition of cerebral microvascular $A \beta$ deposition $(p<0.001)$ (Fig. 3B). These data indicate that apoE is involved with facilitating diffuse $\mathrm{A} \beta$ deposition in the parenchyma of most brain regions but is more essential for promoting robust fibrillar cerebral microvascular deposition in $\mathrm{Tg}-\mathrm{SwDI}$ mice.

\section{Absence of apoE and reduction of cerebral $A \beta$ deposition does not lower total $\mathrm{A} \boldsymbol{\beta}$ levels or soluble $\mathrm{A} \boldsymbol{\beta}$ oligomers in brains of $\mathrm{Tg}-\mathrm{SwDI}$ mice}

Quantitative immunoblotting measurements showed that the absence of apoE had no observable effect on levels of transgeneencoded human A $\beta P P$ levels in $T g-S w D I$ mouse brains (Fig. $4 A, B)$. Likewise, quantitative ELISA analysis showed that $T g$ SwDI/apoE $E^{-/-}$mice have similar levels of forebrain total A $\beta 40$ and $\mathrm{A} \beta 42$ compared with $\mathrm{Tg}$-SwDI/apoE ${ }^{+/+}$mice (Fig. $4 C$ ). The ratio of $A \beta 40: A \beta 42$ was found to be very similar, at $\sim 10: 1$, both in isolated cerebral microvessels and vascular-depleted parenchymal forebrain fractions. To understand why there was a reduction in cerebral $\mathrm{A} \beta$ deposition without a lowering of total $\mathrm{A} \beta$ levels in $\mathrm{Tg}-\mathrm{S} w D I / a p o E^{-/-}$mice, we next compared the amounts of insoluble $\mathrm{A} \beta$ obtained from the guanidine fraction with soluble $A \beta$ obtained from the carbonate fraction from brains of these mice. Lower levels of insoluble $\mathrm{A} \beta$ and higher levels of soluble $\mathrm{A} \beta$ were detected in the $T g-S w D I / a p o E^{-/-}$mice, resulting in a $\approx 50 \%$ reduction in this ratio $(p<0.001)$ (Fig. $5 A$ ), which is consistent with the observed decrease in cerebral $\mathrm{A} \beta$ deposition (Fig. 2). Despite the decrease of insoluble deposited $A \beta$, quantitative dot-blot analysis using a polyclonal antibody specific for soluble A $\beta$ oligomers (Lambert et al., 2001; Chang et al., 2003) revealed an approximate twofold increase in these forms $(p<$ 0.001) (Fig. 5B,C). These findings demonstrate that, although the absence of apoE in Tg-SwDI mice markedly affected deposition of insoluble $\mathrm{A} \beta$, particularly on the cerebral microvascula-
A
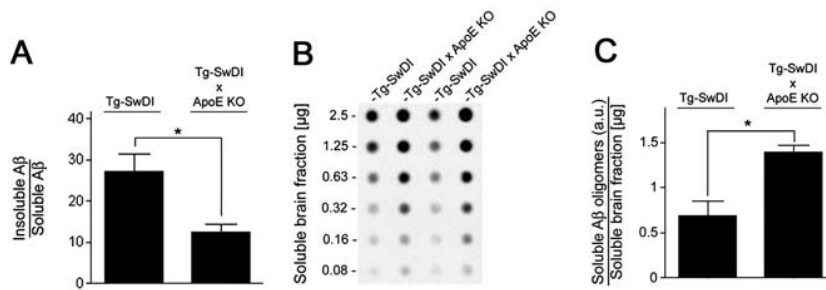

Figure 5. Effects of endogenous mouse apoE on cerebral soluble and insoluble $A \beta$ levels in $\mathrm{Tg}$-SwDI mice. $\boldsymbol{A}$, Ratio of total insoluble $A \beta$ /soluble $A \beta$. $\boldsymbol{B}$, Representative dot-blot analysis of $A \beta$ oligomers in soluble mouse forebrain extracts. $C$, Quantitation of soluble $A \beta$ oligomers from dot blots of $T g$-SwDI and $T g$-SwDI/apoE ${ }^{-1-}$ mice. Data shown are mean $\pm S D(n=5) .{ }^{*} p<$ 0.001. K0, Knock-out.

ture, it had no observable influence on the levels of total brain $\mathrm{A} \beta$ and, notably, elevated the levels of soluble $\mathrm{A} \beta$ oligomers.

\section{Reduction of cerebral microvascular amyloid decreases associated neuroinflammatory cells and IL-1 $\beta$ levels in Tg-SwDI mice}

Recent studies indicate that neuroinflammation is associated with cerebral microvascular $\mathrm{A} \beta$ deposition, where it may contribute to the progressive dementia of $\mathrm{AD}$ and related familial CAA disorders (Grabowski et al., 2001; Atterns and Jellinger, 2004; Eng et al., 2004; Harkness et al., 2004; Maat-Schieman et al., 2004). Specifically, accumulation of reactive astrocytes and activated microglia is found in proximity to fibrillar cerebral microvascular A $\beta$ deposits (Grabowski et al., 2001; Eng et al., 2004). Because $\mathrm{Tg}$-SwDI mice develop fibrillar $\mathrm{A} \beta$ deposition exclusively on the microvasculature (Figs. 1,3 ), they provide a unique model to investigate neuroinflammation driven by microvascular amyloid in the absence of parenchymal fibrillar amyloid. Large numbers of astrocytes exhibiting a reactive ramified appearance were tightly associated with microvessels in $\mathrm{Tg}$-SwDI/ $a p o E^{+/+}$mice (Fig. $6 A, C$ ), whereas the number of these cells was significantly reduced in the $T g-S w D I / a p o E^{-/-}$mice that lack appreciable cerebral microvascular amyloid (Fig. 6B,D). Quantitative stereological measurement of astrocyte densities showed that the highest numbers of these neuroinflammatory cells were found in regions with the most abundant fibrillar cerebral microvascular $\mathrm{A} \beta$ deposition (i.e., thalamus and subiculum) (Fig. 3E).

Similarly, abundant microvascular-associated activated microglia were found in the $T g-S w D I / a p o E^{+/+}$mice (Fig. 7A,C), whereas the numbers of these cells was clearly reduced in the absence of microvascular amyloid (Fig. $7 B, D$ ). Quantitative ste- 


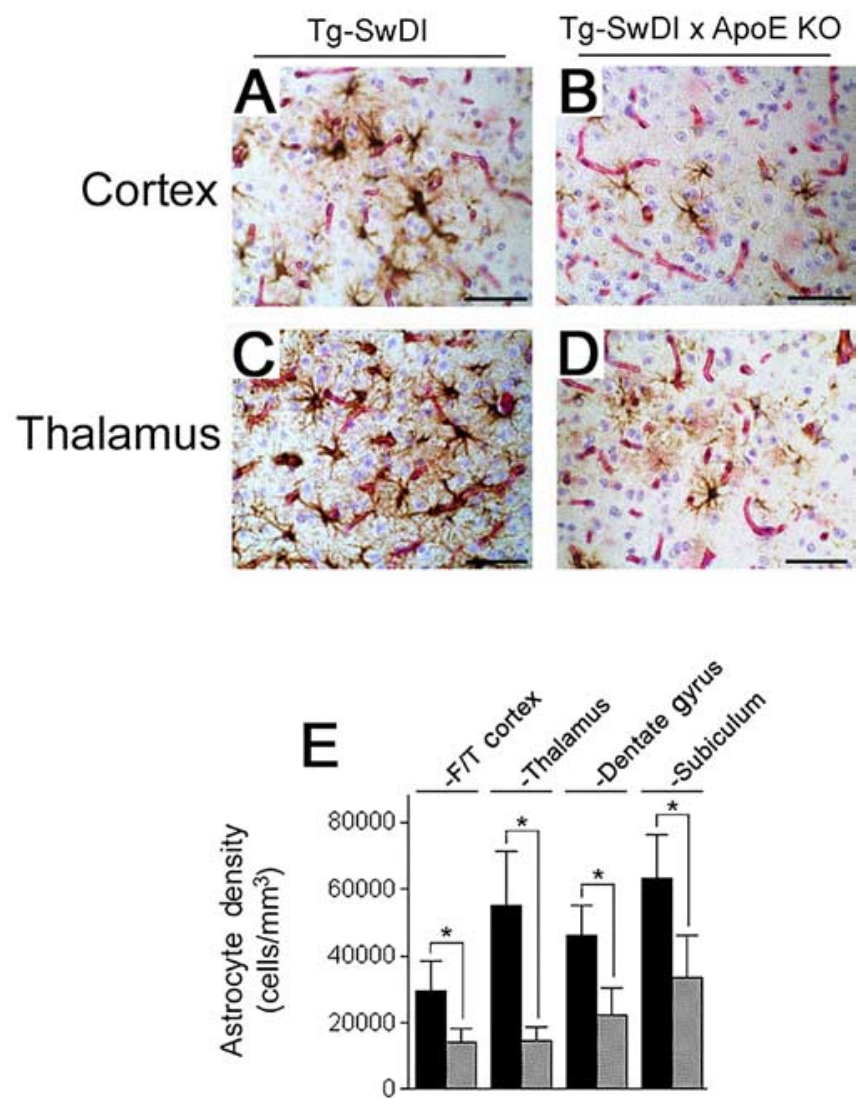

Figure 6. Reduced cerebral microvascular amyloid decreases reactive astrocytes in Tg-SwDI mice. $\boldsymbol{A}-\boldsymbol{D}$, Microvascular-associated reactive astrocytes revealed by GFAP-positive immunostaining (brown) and collagen type IV (red) in $T g$-SwDl mouse frontotemporal cortex $(\boldsymbol{A}, \boldsymbol{B})$ or thalamus $(\boldsymbol{C}, \boldsymbol{D})$ in the presence $(\boldsymbol{A}, \boldsymbol{C})$ or absence $(\boldsymbol{B}, \boldsymbol{D})$ of endogenous mouse apoE. Scale bars, $50 \mu \mathrm{m}$. $\boldsymbol{E}$, Quantitative stereological estimation of reactive astrocyte densities in brain regions of $\mathrm{Tg}$-SWDI mice in the presence (black bars) or absence (gray bars) of endogenous mouse apoE. Data shown are mean $\pm S D(n=10) .{ }^{*} p<0.001$. F/T, Frontotemporal; K0, knock-out.

reological measurement of activated microglial densities also showed that the numbers of these neuroinflammatory cells were, again, the highest in regions with the most abundant fibrillar cerebral microvascular $\mathrm{A} \beta$ deposition (i.e., thalamus and subiculum) (Fig. 7E). Nevertheless, their presence was significantly decreased in all regions of $T g-S w D I / a p o E^{-I-}$ mice compared with $T g$-SwDI/apoE $E^{+/+}$mice $(p<0.01)$ (Fig. $\left.7 E\right)$.

The neuroinflammatory cytokine IL- $1 \beta$ has been shown to be elevated in brain and, notably, in cerebral microvessels from patients with AD (Grammas and Ovase, 2001, 2002). Similarly, we found markedly elevated levels of IL- $1 \beta$ in Tg-SwDI/apoE ${ }^{+/+}$ mice (Fig. 8). However, there was a significant decrease in IL- $1 \beta$ levels in $T g-S w D I / a p o E^{-/-}$mice. Together, these findings indicate that the lowering of cerebral microvascular amyloid in $\mathrm{Tg}-\mathrm{S} w \mathrm{DI}$ mice resulted in a pronounced reduction of associated neuroinflammation.

\section{Discussion}

The present findings show that the strong reduction of fibrillar cerebral microvascular $\mathrm{A} \beta$ deposition in $\mathrm{Tg}-\mathrm{S} w D I$ mice decreases microvascular amyloid-induced neuroinflammation. The $T g$ SwDI mouse is a unique model in that it exclusively develops fibrillar amyloid deposits in the cerebral vasculature, primarily on the microvasculature, whereas $\mathrm{A} \beta$ deposits in the brain parenchyma are primarily diffuse. In $T g-S w D I$ mice, cerebral microvascular amyloid starts to deposit at several months and exten-
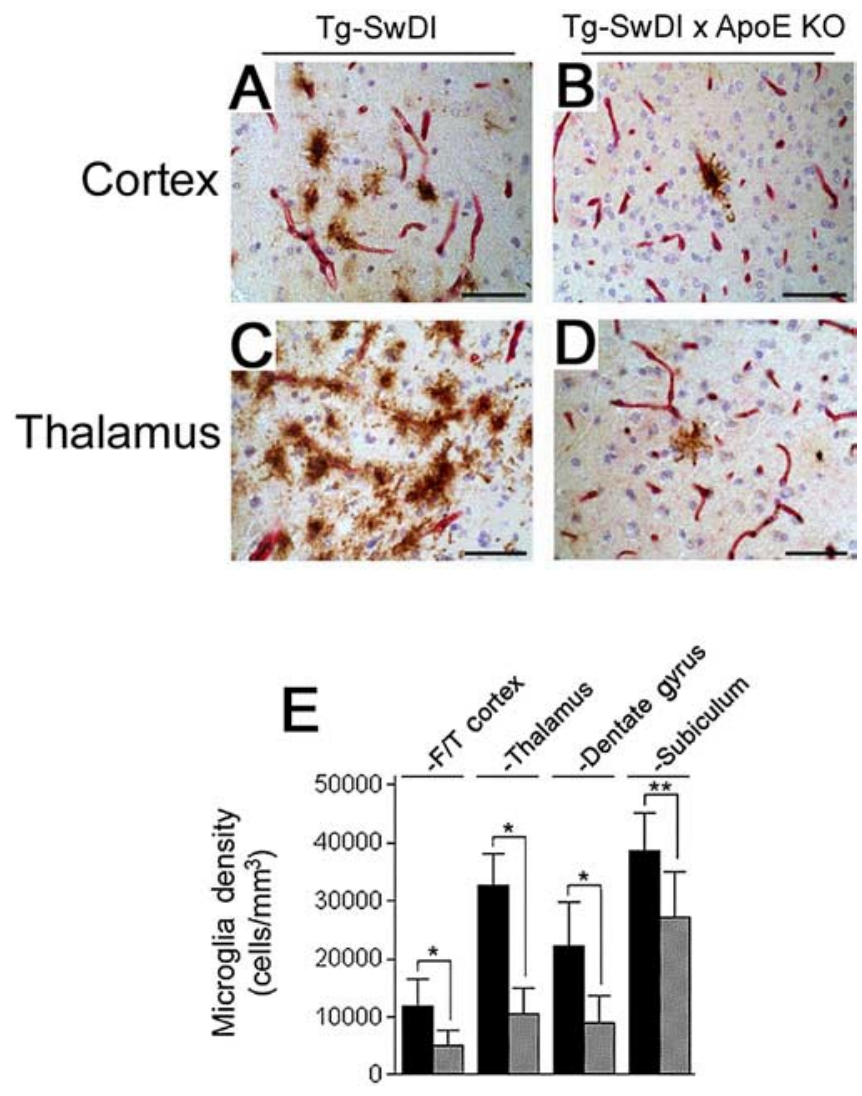

Figure 7. Reduced cerebral microvascular amyloid decreases activated microglia in Tg-SwDI mice. $\boldsymbol{A}-\boldsymbol{D}$, Microvascular-associated activated microglia revealed by 5D4-positive immunostaining (brown) and collagen type IV (red) in Tg-SwDI mouse frontotemporal cortex $(\boldsymbol{A}, \boldsymbol{B})$ or thalamus $(\boldsymbol{C}, \boldsymbol{D})$ in the presence $(\boldsymbol{A}, \boldsymbol{C})$ or absence $(\boldsymbol{B}, \boldsymbol{D})$ of endogenous mouse apoE. Scale bars, $50 \mu \mathrm{m}$. $\boldsymbol{E}$, Quantitative stereological estimation of activated microglial densities in brain regions of Tg-SwDI mice in the presence (black bars) or absence (gray bars) of endogenous mouse apoE. Data shown are mean $\pm S D(n=10) .{ }^{*} p<0.0001 ;{ }^{* *} p<0.01$. F/T, Frontotemporal; K0, knock-out.

sively accumulates as the mice age (Davis et al., 2004). Although cerebral microvascular amyloid accumulation is extensive in this model, associated microhemorrhage is not a robust event. The restriction of fibrillar amyloid solely to the cerebral vasculature accurately reflects the site of fibrillar $\mathrm{A} \beta$ deposition and vascular amyloid-associated neuroinflammation in patients with the Dutch-type or Iowa-type familial CAA disorders (Grabowski et al., 2001; Maat-Schieman et al., 2004).

In several ways, the present study suggests a significant role for cerebral microvascular amyloid deposition in promoting neuroinflammation in amyloid-depositing diseases. First, this study provides novel evidence demonstrating that cerebral microvascular amyloid deposition can solely induce local neuroinflammation in human $\mathrm{A} \beta \mathrm{PP}$ transgenic mice in the absence of parenchymal plaque fibrillar amyloid deposition. The presence of endogenous mouse apoE has been shown to be instrumental in promoting amyloid deposition in other human $\mathrm{A} \beta \mathrm{PP}$ transgenic mouse models (Bales et al., 1999; Holtzman, 2001, 2004; Fryer et al., 2003). Accordingly, using the $a p o E^{-/-}$background as a tool to reduce microvascular amyloid deposition, we show a marked decrease in microvascular-associated neuroinflammatory cells and a significant lowering of neuroinflammatory cytokine IL- $1 \beta$ levels. The present microvascular amyloid findings are consistent with numerous genetic epidemiological as well as in vitro and in vivo studies implicating a strong association between apoE and 


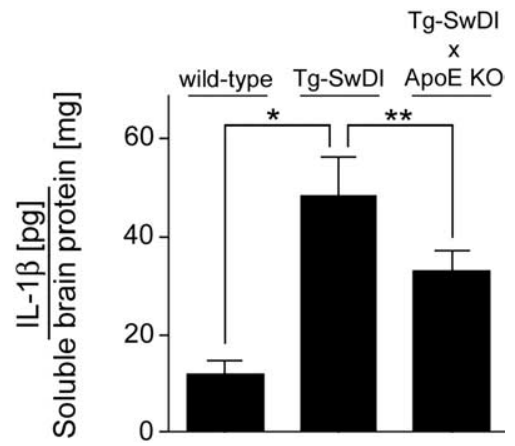

Figure 8. Reduced cerebral microvascular amyloid lowers the elevated IL-1 $\beta$ levels found in $\mathrm{Tg}$-SWDI mice. The levels of IL-1 $\beta$ were measured in soluble forebrain extracts of 12-month-old wild-type, $\mathrm{Tg}$-SWDI/apoE ${ }^{+/+}$, and $\mathrm{Tg}$-SWDI/apoE ${ }^{-/-}$mice by ELISA analysis. Data shown are mean $\pm S D(n=5)$. ${ }^{*}<<0.0002 ;{ }^{* *} p<0.01 . K 0$, Knock-out.

fibrillar $\mathrm{A} \beta$ deposition in brain (Schmechel et al., 1993; Holtzman, 2001; Chalmers et al., 2003; Ashford, 2004; Holtzman, 2004).

Second, our findings indicate that it is the deposited fibrillar forms of $\mathrm{A} \beta$ in the brain insoluble fraction that are strongly associated with inducing neuroinflammation in the Tg-SwDI model. In particular, the neuroinflammatory effects are the most robust in the regions that exhibit the highest amounts of cerebral microvascular amyloid deposition. In this regard, it is notable that elevated levels of inflammatory cytokines, including IL-1 $\beta$, were reported in microvessels isolated from AD patients (Grammas and Ovase, 2001, 2002). Moreover, $A \beta$ treatment was shown to stimulate production of IL- $1 \beta$ in cultured endothelial cells (Suo et al., 1998).

Third, $T g$-SwDI mice are markedly deficient in their ability to clear Dutch/Iowa mutant $\mathrm{A} \beta$ peptides from brain across the blood-brain barrier into the circulation (Davis et al., 2004; Deane et al., 2004). This finding is further supported by the absence of detectable human $\mathrm{A} \beta$ in plasma obtained from $\mathrm{Tg}-\mathrm{S} w \mathrm{DI}$ mice on either an $a p o E^{+/+}$or $a p o E^{-/-}$background (data not shown). Therefore, the $T g$-SwDI model provided a unique opportunity to investigate the effects of modulating $\mathrm{A} \beta$ deposition without altering the total pool of $A \beta$ in brain via clearance into the circulation. Indeed, the lack of apoE drastically reduced $\mathrm{A} \beta$ deposition, particularly on the cerebral microvasculature, without significant influence on the levels of total $\mathrm{A} \beta$ in brain. Soluble $\mathrm{A} \beta$ oligomers have been proposed as potentially key pathogenic mediators of neuronal dysfunction in AD (Gong et al., 2003; Kayed et al., 2003; Cleary et al., 2004). However, despite a marked increase in the amount of soluble $\mathrm{A} \beta$ oligomers when cerebrovascular amyloid was reduced on the $a p o E^{-/-}$background, there was a clear reduction of neuroinflammation. Although these findings do not diminish the potential importance of soluble $\mathrm{A} \beta$ oligomers in the pathogenesis of neurodegenerative diseases, they indicate that cerebral microvascular fibrillar $\mathrm{A} \beta$ deposition can promote neuroinflammation on its own. The significance of pathogenic, vascular-mediated $\mathrm{A} \beta$ fibrillar assembly and deposition is also supported by several previous in vitro results using primary cerebrovascular cell cultures (Van Nostrand et al., 1997; Verbeek et al., 1997; Melchor and Van Nostrand, 2000).

Finally, these data show that fibrillar $\mathrm{A} \beta$ deposition is a viable target for the treatment of cerebral microvascular amyloidinduced neuroinflammation. In fact, recent studies have suggested that treatments aimed at reducing CAA-induced inflammation in afflicted individuals have improved the dementia associated with this particular pathology (Eng et al., 2004; Harkness et al., 2004). Because CAA pathology is commonly found in $\mathrm{AD}$, this target may have additional implications in combined treatment strategies for this neurodegenerative condition and its related disorder. As the present findings suggest, the interaction between $\mathrm{A} \beta$ and apoE that facilitates cerebral microvascular amyloid deposition leading to neuroinflammation represents one such target. Furthermore, these results indicate that disruption of pathogenic fibrillar amyloid remains an attractive therapeutic goal, and $T g-S w D I$ mice provide a unique model to test such approaches.

\section{References}

Ashford JW (2004) APOE genotype effects on Alzheimer's disease onset and epidemiology. J Mol Neurosci 23:157-165.

Atterns J, Jellinger KA (2004) Only cerebral capillary amyloid angiopathy correlates with Alzheimer pathology—a pilot study. Acta Neuropathol 107:83-90.

Bailey TL, Rivara CB, Rocher AB, Hof PR (2004) The nature and effects of cortical microvascular pathology in aging and Alzheimer's disease. Neurol Res 26:573-578.

Bales KR, Verina T, Cummins DJ, Du Y, Dodel RC, Saura J, Fishman CE, DeLong CA, Piccardo P, Petegnief V, Ghetti B, Paul SM (1999) Apolipoprotein E is essential for amyloid deposition in the APPV717F transgenic mouse model of Alzheimer's disease. Proc Natl Acad Sci USA 96:15233-15238.

Chalmers K, Wilcock GK, Love S (2003) APOE $\epsilon 4$ influences the pathological phenotype of Alzheimer's disease by favouring cerebrovascular over parenchymal accumulation of A $\beta$ protein. Neuropathol Appl Neurobiol 29:231-238.

Chang L, Bakhos L, Wang Z, Venton DL, Klein WL (2003) Femtomole immunodetection of synthetic and endogenous amyloid $\beta$-oligomers and its application to Alzheimer's disease drug candidate screening. J Mol Neurosci 20:305-313.

Cleary JP, Walsh DM, Hofmeister JJ, Shankar GM, Kuskowski MA, Selkoe DJ, Ashe KH (2004) Natural oligomers of the amyloid- $\beta$ protein specifically disrupt cognitive function. Nat Neurosci 8:79-84.

Davis J, Xu F, Deane R, Romanov G, Previti ML, Zeigler K, Zlokovic BV, Van Nostrand WE (2004) Early-onset and robust cerebral microvascular accumulation of amyloid $\beta$-protein in transgenic mice expressing low levels of a vasculotropic Dutch/Iowa mutant form of amyloid $\beta$-protein precursor. J Biol Chem 279:20296-20306.

Deane R, Du Yan S, Submamaryan RK, LaRue B, Jovanovic S, Hogg E, Welch D, Manness L, Lin C, Yu J, Zhu H, Ghiso J, Frangione B, Stern A, Schmidt AM, Armstrong DL, Arnold B, Liliensiek B, Nawroth P, Hofman F, et al. (2003) RAGE mediates amyloid $\beta$-peptide transport across the bloodbrain barrier and accumulation in brain. Nat Med 9:907-913.

Deane R, Wu Z, Sagare A, Davis J, Yan SD, Hamm K, Xu F, Parisi M, LaRue B, Hu HW, Spijkers P, Guo H, Song X, Lenting PJ, Van Nostrand WE, Zlokovic BV (2004) LRP-amyloid $\beta$-peptide $(\mathrm{A} \beta$ ) interaction regulates differential brain efflux of $A \beta$ isoforms. Neuron 43:333-344.

DeMattos RB, O’Dell MA, Parsadanian M, Taylor JW, Harmony JA, Bales KR, Paul SM, Aronow BJ, Holtzman DM (2002) Clusterin promotes amyloid plaque formation and is critical for neuritic toxicity in a mouse model of Alzheimer's disease. Proc Natl Acad Sci USA 99:10843-10848.

Dickson DW, Wertkin A, Mattiace LA, Fier E, Kress Y, Davies P, Yen SH (1990) Ubiquitin immunoelectron microscopy of dystrophic neurites in cerebellar senile plaques of Alzheimer's disease. Acta Neuropath (Berl) 79:486-493.

Eng JA, Frosch MP, Choi K, Rebeck GW, Greenberg SM (2004) Clinical manifestations of cerebral amyloid angiopathy-related inflammation. Ann Neurol 55:250-256.

Fryer JD, Taylor JW, DeMattos RB, Bales KR, Paul SM, Parasdanian M, Holtzman DM (2003) Apolipoprotein E markedly facilitates agedependent cerebral amyloid angiopathy and spontaneous hemorrhage in amyloid precursor protein transgenic mice. J Neurosci 23:7889-7896.

Gong Y, Chang L, Viola KL, Lacor PN, Lambert MP, Finch CE, Krafft GA, Klein WL (2003) Alzheimer's disease-affected brain: presence of oligomeric $A \beta$ ligands (ADDLs) suggests a molecular basis for reversible memory loss. Proc Natl Acad Sci USA 100:10417-10422.

Grabowski TJ, Cho HS, Vonsattel JPG, Rebeck GW, Greenberg SM (2001) Novel amyloid precursor protein mutation in an Iowa family with dementia and severe cerebral amyloid angiopathy. Ann Neurol 49:697-705. Grammas P, Ovase R (2001) Inflammatory factors are elevated in brain microvessels in Alzheimer's disease. Neurobiol Aging 22:837-842.

Grammas P, Ovase R (2002) Cerebrovascular transforming growth factor- 
beta contributes to neuroinflammation in the Alzheimer's disease brain. Am J Pathol 160:1583-1587.

Greenberg SM, Gurol ME, Rosand J, Smith EE (2004) Amyloid angiopathyrelated vascular cognitive impairment. Stroke 35:2616-2619.

Harkness KA, Coles A, Pohl U, Xuereb JH, Baron JC, Lennox GG (2004) Rapidly reversible dementia in cerebral amyloid inflammatory vasculopathy. Eur J Neurol 11:59-62.

Holtzman DM (2001) Role of apoE/A $\beta$ interactions in the pathogenesis of Alzheimer's disease and cerebral amyloid angiopathy. J Mol Neurosci 17:147-155.

Holtzman DM (2004) In vivo effects of ApoE and clusterin on amyloid- $\beta$ metabolism and neuropathology. J Mol Neurosci 23:247-254.

Jellinger KA (2002) Alzheimer disease and cerebrovascular pathology: an update. J Neural Transm 109:813-836.

Johnson-Wood K, Lee M, Motter R, Hu K, Gordon G, Barbour R, Khan K, Gordon M, Tan H, Games D, Lieberburg I, Schenk D, Seubert P, McConlogue L (1997) Amyloid precursor protein processing and A $\beta 42$ deposition in a transgenic mouse model of Alzheimer's disease. Proc Natl Acad Sci USA 94:1550-1555.

Kayed R, Head E, Thompson JL, McIntire TM, Milton SC, Cotman CW, Glabe CG (2003) Common structure of soluble amyloid oligomers implies common mechanism of pathogenesis. Science 300:486-489.

Lambert MP, Viola KL, Chromy BA, Chang L, Morgan TE, Yu J, Venton DL, Krafft GA, Finch CE, Klein WL (2001) Vaccination with soluble A $\beta$ oligomers generates toxicity-neutralizing antibodies. J Neurochem 79:595-605.

Levy E, Carman MD, Fernandez-Madrid IJ, Power MD, Lieberbur I, van Duinen SG, Bots GT, Luyendijk W, Frangione B (1990) Mutation of the Alzheimer's disease amyloid gene in hereditary cerebral hemorrhage, Dutch type. Science 248:1124-1126.

Long JM, Kalehua AN, Muth NJ, Calhoun ME, Jucker M, Hengemihle JM, Ingram DK, Mouton PR (1998) Stereological estimation of total microglia number in mouse hippocampus. J Neurosci Methods 84:101-108.

Maat-Schieman MLC, Yamaguchi H, Hegeman-Kleinn I, Welling-Graafland C, Natte R, Roos RAC, van Duinen SG (2004) Glial reactions and the clearance of amyloid $\beta$ protein in the brains of patients with hereditary cerebral hemorrhage with amyloidosis-Dutch type. Acta Neuropathol 107:389-398.

Melchor JP, Van Nostrand WE (2000) Fibrillar amyloid $\beta$-protein mediates the pathologic accumulation of its secreted precursor in human cerebrovascular smooth muscle cells. J Biol Chem 275:9782-9791.

Neuropathology Group of the Medical Research Council Cognitive Function and Ageing Study (2001) Pathological correlates of late-onset dementia in a multicentre, community-based population in England and Wales. Lancet 357:169-175.

Rensink AA, de Waal RM, Kremer B, Verbeek MM (2003) Pathogenesis of cerebral amyloid angiopathy. Brain Res Brain Res Rev 43:207-223.

Schmechel DE, Saunders AM, Strittmatter WJ, Crain BJ, Hulette CM, Joo SH, Pericak-Vance MA, Goldgaber D, Roses AD (1993) Increased amyloid $\beta$-peptide deposition in cerebral cortex as a consequence of apolipoprotein genotype in late-onset Alzheimer's disease. Proc Natl Acad Sci USA 90:9649-9653.

Selkoe DJ (2001) Alzheimer's disease: genes, proteins, and therapy. Physiol Rev 8:741-766.

Suo Z, Tan J, Placzek A, Crawford F, Fang C, Mullan M (1998) Alzheimer's beta-amyloid peptides induce inflammatory cascade in human vascular cells: the roles of cytokines and CD40. Brain Res 807:110-117.

Thal DR, Ghebremedhin E, Orantes M, Wiestler OD (2003) Vascular pathology in Alzheimer's disease: correlation of cerebral amyloid angiopathy and arteriosclerosis/lipohyalinosis with cognitive decline. J Neuropathol Exp Neurol 62:1287-1301.

Van Broeckhoven C, Haan J, Bakker E, Hardy JA, Van Hul W, Wehnert A, Vegter Van der Vlis M, Roos RA (1990) Amyloid beta protein precursor gene and hereditary cerebral hemorrhage with amyloidosis (Dutch). Science 248:1120-1122.

Van Nostrand WE, Melchor J, Ruffini L (1997) Pathologic cell surface amyloid $\beta$-protein fibril assembly in cultured human cerebrovascular smooth muscle cells. J Neurochem 69:216-223.

Verbeek MM, de Waal RM, Schipper JJ, Van Nostrand WE (1997) Rapid degeneration of cultured human brain pericytes by amyloid $\beta$-protein. J Neurochem 68:1135-1141.

Vinters HV (1987) Cerebral amyloid angiopathy: a critical review. Stroke $18: 311-324$

Vinters HV (2001) Cerebral amyloid angiopathy: a microvascular link between parenchymal and vascular dementia? Ann Neurol 49:691-692. 